\title{
10
}

\section{A collection of impossible ideas}

\author{
Rebecca Giblin and Kimberlee Weatherall'
}

\section{This is a collection of impossible ideas}

As flagged in the introduction, this book's contributions exhibit rich divergence: they identify the aims of copyright differently, offer a variety of conceptions of the 'public interest', and sometimes fundamentally disagree with one another. We do not, in this book, offer one coherent vision for a future, redesigned, ideal copyright law. We are reimagining copyright law - and much more debate is needed, from a larger variety of stakeholders, before solutions might be found. But nonetheless, these collected chapters combine to provide some salient themes and lessons which recur throughout the book.

This concluding chapter is not intended to merely summarise the collected chapters: each is a complex and standalone set of ideas, and each deserves its own reading. Instead, the questions we want to explore in this final instalment speak to a bigger picture. First, what are those common threads or ideas for a reconception of copyright in the public interest: when our authors took a step back, what were some of their core reimaginings? Second, how achievable are those

1 In writing this chapter the authors benefited from discussions with a range of experts, including in particular Professor Sam Ricketson (University of Melbourne), Professor Tim Stephens (University of Sydney), and Professor Chester Brown (University of Sydney). We thank them for their assistance; any errors are of course our own. 
ideas on the spectrum from attainable to pipedream? And finally, where to from here? Is this collection is merely an ode to what 'could have been', or, impossible or not, do the ideas here still have a role to play in the current debates racking international and national copyright systems?

\section{Emerging themes and ideas}

\section{Designing copyright 'in the public interest' means giving more to authors}

The first common theme that emerges strongly from these collected chapters is that, when invited to think about the design of copyright in the public interest, most of our contributors evinced a concern that current copyright rules do a poor job of protecting the interests of individual authors and creators. Many chapters are informed by a desire for a system that would better recognise authors' ongoing interests in their works and better reward them for their creative labour. These motivations are reflected in a wide range of suggestions: incorporation of a more nuanced understanding of the variegated goals of different kinds of artists (Senftleben); facilitation of ongoing author involvement in the exploitation of their creative works in order to better secure to them the fruits of their labours (Senftleben, Giblin); promoting opportunities for authors to write in their own languages (Ncube); or facilitating collective bargaining (de Beer). These chapters don't write out other important players such as producers and publishers from copyright either. Unfragmented ownership along the lines of de Beer's suggestions might demand a different industry structure but would not suggest an absence of intermediaries; Giblin's proposals on term and Gangjee's proposals regarding registration would explicitly protect and encourage the distinct contributions and investments of producers as well as those of creators.

In other words, when this book talks about the public interest in copyright, it is never as a proxy for user interests or consumer interests. Quite the contrary: whether contributors reimagined copyright via a conception built upon a preponderance of interests, or from the perspective of a representative individual sitting behind a veil of ignorance, they recognised the importance of supporting creativity, 
and ensuring a rich and productive cultural life, and have made suggestions for better accommodating various competing interests. The ideas in these chapters are not a menu of ways to destroy rights. They are ideas for unlocking some of the value for creators and society as a whole that are blocked under current system, and for making the pie bigger for all.

\section{An increased role for reciprocity}

Reciprocity is a second key thread that runs through this collection. Many of the contributing authors have argued that, if copyright is to serve the public interest, it is going to require some measure of reciprocity. This understanding of copyright implies both rights and duties or responsibilities for everyone: users, creators and others. As Gangjee puts it in his chapter, '[t]here is so much we could be asking of those making a claim to copyright protection, which we refrain from asking, [and this is] in stark contrast to most other areas of IP [intellectual property] law'.

Copyright has rarely been thought of this way: the international legal framework is very clear about the obligations of users and the public generally in relation to copyright - chief among these being a duty not to infringe. ${ }^{2}$ It was not until the Marrakesh Treaty to Facilitate Access to Published Works for Persons who are Blind, Visually Impaired or Otherwise Print Disabled was settled in 2013 that significant internationally mandated minimums for access were recognised, ${ }^{3}$ and even these are expressed as exceptions rather than as reciprocal obligations of copyright owners. ${ }^{4}$ Nonetheless, one of copyright's most fundamental justifications is that it provides benefits to the public. The theory of copyright which is embodied in current international frameworks and domestic laws appears to be that if the rights are taken care of, the public's benefits in the form of distribution and access

2 Sometimes copyright imposes additional positive duties: larger institutional users sometimes have positive duties to keep copies secure or ensure they are not used for unapproved purposes. 3 Although it is worth noting the mandatory requirement to make quotations permissible, found in Berne Convention, see n 7, Art 10.1.

4 See Rebecca Giblin, 'Is it copyright's role to fill houses with books?' in Susy Frankel and Daniel Gervais (eds), The Internet and Intellectual Property: The Nexus with Human and Economic Development (Victoria University Press, forthcoming) <ssrn.com/abstract $=2853970>$; Paul Harpur and Nicolas Suzor, 'Copyright Protections and Disability Rights: Turning the Page to a new International Paradigm’ (2013) 36(3) University of NSW Law Journal 745. 
will take care of themselves - after all, what rational copyright owner would refuse to make their material available on commercial terms? And yet we know for a fact that access to copyright material is not evenly distributed: work towards the Marrakesh Treaty highlighted the book famine suffered by those with print disabilities; ${ }^{5}$ Ncube's chapter highlights the serious dearth of access to material for significant populations who do not speak English or some other dominant language, and the scale of the orphan works problem demonstrates that society regularly values and demands access to works in which their owners have no interest in exploiting.

This collection's authors wouldn't leave access so much to chance. Instead, they have imagined a much more distributed group of rights and duties and a greater engagement with issues of distributive justice. Geiger and Weatherall, for example, both suggest some form of positive duty of dissemination on copyright owners: Geiger as a standalone duty; Weatherall as a condition precedent to the application of public resources on enforcement. Ncube's proposals include a different kind of 'use it or lose it' principle, conditioning a continuing right to distribute translations on an owner's exploitation of that right. Both Gangjee and Giblin would require creators to positively demonstrate some minimal interest in continued protection after an initial fixed period in order to trigger additional rights, and Senftleben suggests a greater level of give and take as between authors: author's rights, he suggests, include a right to reuse and critique others' material. De Beer's chapter, while endorsing copyright as a market mechanism, nevertheless still recognises that other issues such as access may need to be addressed (albeit while arguing that the best mechanisms for so doing lie outside the copyright system).

Issues like distribution and access loom large when you place yourself, like Ho's Representative Individual, behind a veil of ignorance, and face a possible future where you are not endowed with the resources to thrive in a world of user-pays access to culture and knowledge. ${ }^{6}$ It is easy to be blasé about questions of access from a position of privilege. If, however, you come at the matter from the perspective of having an even chance of belonging in the less-well-resourced half of the global population, would you be happy trusting entirely to the market and

5 See e.g. Giblin, above $\mathrm{n} 4$.

6 For a more detailed exploration of this point see Giblin, above n 4 . 
the good offices of copyright owners for your ability to participate in global culture? Or would you ensure the benefits of copyright come with at least some minimal obligations to broader society? Try this ex ante approach on others, and see how quickly their focus switches from rights of protection to rights of access.

\section{One size does not necessarily fit all}

A third theme observable in a number of these collected chapters is the idea that one size does not necessarily fit all - and that one way to address this might be through 'phased' rights. Not all right holders have the same interests or concerns. Both Giblin and Gangjee, in seeking to design systems responsive to both the needs of commercial producers and distributors on the one hand, and individual creators on the other, proposed phases of copyright. Those two contributions independently proposed an initial short period of protection in recognition of creators' interests in their works, and as a way of levelling the playing field between individual creators and better resourced corporations. After this initial period, Gangjee's proposal would see protection for economic rights secured through obligatory registration for the remaining term of protection. Giblin's proposal, reflecting the reality that not all works need and not all creators want the same term, would set terms that march with their ongoing interests in their works. Recognising that creators' ongoing personal interests in works could outlast the economic, both contributions emphasised the need for moral rights (such as right of attribution and integrity) that would remain available regardless of copyright or registration status. Ncube's proposal also demonstrates how one size doesn't fit all, this time along the dimensions of access and development. With reference to the dire shortage of literature in neglected languages, she calls for greater rights over translation and use as a way of furthering human and economic development.

\section{Are these impossible ideas?}

The proposals collected here, then, imagine (to a greater or lesser degree) a differently conceived copyright: one that recognises the distinct interests of human creators, while also placing a higher importance on reciprocity and ensuring society gets its quid pro quo. 
This leaves us with a very important question. The project started by asking contributors not to worry about the international legal framework. Now though, we do have to ask: how big a constraint is it on the ideas that we've proposed?

A great deal of the commentary in this area is premised on the idea that, as awareness grows about the inefficiencies and lost culture brought about by current approaches, change at the treaty level will follow. We very much wanted this book to end on a similarly positive and hopeful note. Ultimately though, the more deeply we explored these questions, the more our attempts to do so felt naive.

The truth of the matter is that the really significant changes mooted here - the ones that would bring about paradigmatic change in the way copyright operates, improving outcomes for creators and society as a whole - require rethinking longstanding international rules. Berne's minimum term of life plus 50 for copyright works dates back to $1948 .^{7}$ Its blanket ban on formalities as a condition of the enjoyment and exercise of rights was decided the year the first Model T's started rolling off Ford's production line. ${ }^{8}$

Today, these rules have been inextricably woven into the international economic order. When one actually sits down and tries to chart a pathway to treaty reform, it becomes apparent that the prospect of substantial change is illusory. No matter how much sense it might make to require copyright owners to assert some continuing interest in their works, or to rethink terms to better align with what copyright is intended to achieve, Berne's mandated minimum terms and prohibition on formalities simply. Won't. Budge.

7 Berne Convention for the Protection of Literary and Artistic Works, opened for signature 9 September 1886 (amended in 1914, 1928, 1948, 1967, 1971, and 1979) 25 UST 1341, 828 UNTS 221, entered into force 5 December 1887 ('Berne Convention'), Art 7(1). Shorter terms are possible for cinematographic works, anonymous and pseudonymous works, photographs and applied art (Art 7(3)-7(5)). For jointly authored works, the time clock starts ticking from demise of last surviving author (Art 7 bis). The life +50 minimum was first recommended in the Berlin Act of 1908, and became mandatory from the Brussels Revision in 1948.

8 Berne Convention, Art 5(2); introduced as part of the Berlin Act of 1908; Marrakesh Agreement Establishing the World Trade Organization, opened for signature 15 April 1994, 1867 UNTS 3 (entered into force 1 January 1995), annex IC (Agreement on Trade-Related Aspects of Intellectual Property Rights) ('TRIPS'), Art 9. 
In large part that's because the treaty requires unanimity of votes cast for its substantive provisions to be revised. ${ }^{9}$ Thus every single member nation effectively has a veto right, from tiny Portuguesespeaking West African nation the Democratic Republic of São Tomé and Príncipe to 170 -odd others. ${ }^{10}$ The difficulties associated with making law to bind so many countries with such divergent interests are hinted at in the current drought between revisions. Berne has not been revised since 1971. That's zero substantive changes in the digital and internet eras, and just one since we put a man on the moon. By contrast, there were seven revisions between 1971 and Berne's inception (averaging one every 12 years), and the longest pause before now was the 20 years between Rome (1928) and Brussels (1948), a time when the world was largely preoccupied with larger geopolitical concerns. But from where we stand right now, amidst increasingly fractious and polarised debates, it actually seems possible that Berne may never be amended again.

This reality forecloses even compromise solutions, such as Landes and Posner's proposal for 'indefinitely renewable copyrights'. The largest practical barriers to shorter terms are the interests of the authors and intermediaries whose works retain commercial value in the decades after creation (or who hope they will). Landes and Posner propose to give these interest groups more of what they want (copyrights that last more or less forever) in exchange for what society needs (freer access to more stuff, sooner). Their scheme would permit right holders with continuing interests in their works to renew them ad infinitum, enabling at least those unwanted or less valued works to enter into the public domain. ${ }^{11}$ As Giblin points out, such a system is not justifiable on any recognised rationale for copyright protection, but it would

9 Berne Convention, Art 27. Note that the requirement of unanimity applies not only to the provisions of the 'Berne Convention Proper', but also to the Berne Appendix. This poses challenges to Ncube's proposals in this book for a radical broadening of the circumstances in which translations of under-exploited works may occur. This is exactly what the Berne Appendix was meant to do, but perhaps because the process by which the Appendix was developed was strongly influenced by first world publishers and authors, the resulting 'flexibilities' have proved so complex, unwieldy and unworkable in practice as to have been almost entirely forsaken by their putative beneficiaries (see also Giblin, above n 4). Whether the Berne Appendix could simply be 'abandoned' and a new treaty regarding translation written (in the style of the recent Marrakesh Treaty) raises interesting questions of international law well beyond the scope of this chapter.

10 See WIPO-Administered Treaties Contracting Parties > Berne Convention <www.wipo.int/ treaties/en/ShowResults.jsp?treaty_id=15>.

11 William M Landes and Richard A Posner, 'Indefinitely Renewable Copyright' (2003) 70 University of Chicago Law Review 471, 517-518. 
at least do something to address some of the worst wastages that flow inevitably from existing approaches. But even such a compromise simply wouldn't possible unless all Berne member states agree - or unless we walk away from Berne and start again.

That's where the rock comes along to join the hard place. Berne is impossible to amend, but walking away from it is scarcely more thinkable. TRIPS' express linking of Berne to membership of the WTO is one reason for that, and the loss of reciprocal rights - in an increasingly borderless digital world - is another. This is a hostage situation we can't see anyone walking away from.

It is possible, albeit with a great deal of difficulty, to create new treaties in this space. We saw this with Marrakesh's recognition of greater access rights for the blind and vision impaired, and before that, the WIPO Copyright and Performances and Phonograms treaties (WIPO Copyright Treaty and WPPT, respectively). Crucially though, Berne itself limits the possibility of new treaties to those that do not detract from its prohibitions and minimums. ${ }^{12}$ This raises complex questions of interpretation of international law, but it seems likely that we could not even fix our formalities or duration problems via entry to a new multilateral agreement.

Cutting the Berne/TRIPS tie is also effectively impossible, because TRIPS itself is also practically unamendable. Proposals for amendments altering members' rights and obligations can be made, but require acceptance by two-thirds of the members (i.e. by 108 of the present 162 WTO members) in order to come into effect, and even then apply only to accepting members. To make an amendment effective for all WTO members requires the Ministerial Conference (i.e. all members in conference) to decide by a three-fourths majority that it is of such a nature that any member which has not accepted it within a specified period should be free to withdraw from the WTO or to remain a member only with the consent of the Ministerial Conference. As a practical matter, voting rarely occurs in the WTO system: most decisions are made by consensus. ${ }^{13}$ The effectively unamendable nature of TRIPS is demonstrated by the fact that the TRIPS Amendment needed to make

12 See Berne Convention, Arts 20, 30.

13 Mitsuo Matsushita, Thomas J Schoenbaum and Petros C Mavroidis, The World Trade Organization: Law, Practice, and Policy (Oxford University Press, 2006), 12. 
permanent the Doha Declaration accommodations to facilitate access to essential medicines for developing countries has still not garnered the needed two-thirds of member acceptances to come into force, despite being supported by a consensus in the General Council over a decade ago in December 2005 (WTO members in late 2015 voted themselves a fifth extension of the deadline for acceptance).

Note too that if TRIPS really is unamendable in any practical sense, this precludes even less significant changes to copyright, and even those for which a supportive industry coalition might be formed. For example, Reese suggested that computer software might be better protected via some sui generis regime than via copyright. There was in fact considerable debate over whether copyright was an appropriate source of protection given the functional nature of programming, and considerable dissatisfaction with software copyrights remains a generation later, shared across big business, individual programmers and the free and open source software communities alike. In these circumstances, the beneficiaries ${ }^{14}$ of software copyright might, perhaps, be willing to abandon it in exchange for a better-tailored sui generis scheme. But TRIPS ${ }^{15}$ and the WIPO Copyright Treaty ${ }^{16}$ both require software (whether in source or object code) to be protected as a literary work in accordance with Berne: which feels like an end to the debate before it can even get started.

Treaty lock-ins severely curtail our ability to respond to changed circumstances in other ways as well. The key goal de Beer identifies for a reconceived copyright is to make copyright a better market facilitator, particularly by addressing fragmented copyright ownership, which imposes transaction costs which can prevent authors, owners and users from reaching mutually beneficial deals. Existing, extremely long-lived property rights stand in the way of any attempt to reduce fragmentation beyond a 'tinkering' via collective licensing. A number of the rules in the international legal framework would also require

\footnotetext{
14 William M Landes and Richard A Posner, 'Indefinitely Renewable Copyright' (2003) 70 University of Chicago Law Review 471, 483.

15 TRIPS, Art 10; World Intellectual Property Organization Copyright Treaty, opened for signature 20 December 1996, 36 ILM 65, entered into force 6 March 2002, Art 4 ('WIPO Copyright Treaty'). They also require the owners of computer programs to be granted a rental right, at least where the program is the essential object of the rental: TRIPS, Art 11; WIPO Copyright Treaty, Art 7.

16 The WIPO Copyright Treaty, which also mandates protection of software as a literary work, contains no provisions for its own amendment, although it can be denounced: Art 23.
} 
amendment to fully achieve de Beer's vision, including, in particular, treaties such as Berne, TRIPS, the WIPO Copyright Treaty and the WIPO Performances and Phonograms Treaty, which grant identical, strong, exclusive rights to a series of different contributors to any given cultural product (authors, performers and producers). ${ }^{17}$

It is worth pausing a moment here to note another implication of our analysis. A great deal of concern has been expressed in the academic and policy literature about the way in which bilateral and regional trade agreements and rules have become more and more specific over time, with particular animus directed towards treaties such as the US trade agreements which export specific rules of US domestic law. It may be that the specificity of more recent treaties (as well as rapid technological change) is a reason why their constraints have been felt more rapidly. It took close to a century for mainstream copyright reform debates to progress to explicit criticism of Berne's prohibition on formalities, for example. ${ }^{18}$ By contrast, some of the AustraliaUnited States Free Trade Agreement's provisions have already caused problems within the first decade of the Agreement being signed. ${ }^{19}$

But some current literature would seem to suggest, at least implicitly, that we should be aiming for a return to the higher level principles embodied in older treaties, such as the Berne Convention. Free exploration by the authors in this book, however, suggests that this may be a misconception. In fact, longstanding, generally drafted provisions of the Berne Convention impose constraints at least as great as the new agreements.

17 Berne Convention, Arts 8, 9, 11 bis, 11ter, 12; WIPO Copyright Treaty, above n 15, Arts 6-8; World Intellectual Property Organization Performances and Phonograms Treaty ('WPPT'), opened for signature 20 December 1996, 36 ILM 76 (entered into force 20 May 2002), Arts 6-8 and 11-13. 18 See Kimberlee G Weatherall, 'So Call Me a Copyright Radical' (2011) 29(4) Copyright Reporter, 123 and literature cited therein.

19 Australia-United States Free Trade Agreement, opened for signature 6 May 2004, signed 18 May 2004, [2005] ATS 1 (entered into force 1 January 2005) Kimberlee G Weatherall, 'The Australia-US free trade agreement's impact on Australia's copyright trade policy' (2015) 69(5) Australian Journal of International Affairs 538; notable in rewording of some US FTA provisions in the context of TPP negotiations and absence of certain provisions in TPP drafts. 


\section{Is it all impossible?}

The forbidding practical barriers to many of the most interesting and important ideas in this book may not stand in the way of some smaller changes that would help improve the system. For the most part, implementing these would involve more fully exploiting existing flexibilities within Berne and TRIPS.

One area where there is obviously flexibility lies in exceptions and limitations. A number of contributors identified a need to expand these to better fulfil the public interest in copyright, and no doubt some steps could be taken in this direction. Of particular potential are fair uses involving quotation, which, as Senftleben points out, Berne positively obliges members to exempt from the copyright owner's control. ${ }^{20}$ Senftleben argues that this could be interpreted as a positive right to transformative use $\mathrm{e}^{21}$ - a possibility that is worthy of serious thought and exploration, especially in light of our authors' desire to promote the interests of individual creators.

Outside of the quotation right (and a few other privileged categories), the ability of individual nations to introduce limitations and exceptions is curbed by the 'three-step test'. Originating in Berne, ${ }^{22}$ then adapted and incorporated into a number of other international instruments including TRIPS, ${ }^{23}$ the WIPO Copyright Treaty, ${ }^{24}$ the WPPT, ${ }^{25}$ various free trade agreements ${ }^{26}$ and a swathe of EU Directives touching on IP-related rights, ${ }^{27}$ this test limits most exceptions and limitations to 'certain special cases that do not conflict with a normal exploitation of the work and do not unreasonably prejudice the legitimate interests of the author'. This tends to preclude exceptions that would remove

\footnotetext{
20 Martin Senftleben, Chapter 2, this volume.

21 Ibid.

22 Berne Convention, Art 9.

23 TRIPS, Art 13.

24 WIPO Copyright Treaty, Art 10.

25 WPPT, Art 16.

26 See e.g. Australia-United States Free Trade Agreement, opened for signature 6 May 2004, signed 18 May 2004, [2005] ATS 1 (entered into force 1 January 2005) Art 17.4(10).

27 See e.g. Directive 2009/24/EC of the European Parliament and of the Council of 23 April 2009 on the legal protection of computer programs [2009] OJ L111/16, Art 6(3); Directive 96/9/EC of the European Parliament and of the Council of 11 March 1996 on the legal protection of databases [1996] OJ L077/20, Art 6(3); and Directive 2001/29\EC of the European Parliament and of the Council of 22 May 2001 on the harmonisation of certain aspects of copyright and related rights in the information society [2001] OJ L167/10, Art 5(5).
} 
any given exclusive right or subsume substantial parts of a copyright owner's rights (even if they make objective sense, and indeed even if they cause little harm to copyright owners). Nonetheless, there remains considerable scope to develop the exceptions of most domestic laws to more fully take advantage of what is permitted - for example, by introducing flexible exceptions in the style of the US 'fair use'. That said, Giblin's proposal to progressively reserve a greater share of each work's value to the public over time, Ncube's call for broader exceptions to help rectify the failure of markets to produce works for the benefit of less advantaged language groups, and the broader approaches to users' and creators' rights proposed by Senftleben and Geiger may each fall foul of this rule, and thus simply not even be eligible for consideration or debate.

The enforcement area has perhaps the most interesting potential flexibility under current treaty arrangements. There is nothing in existing treaties barring governments from taking into account the degree of access their residents have to copyright works in establishing remedies for infringement, or directing their courts to frame remedies with degrees of access in mind. It might not be possible to foreclose the possibility of remedies entirely, even for works that are not made commercially available. ${ }^{28}$ Nevertheless, flexibilities around enforcement could help ameliorate some of the big problems caused by current approaches, and reflect values such as reciprocity which are a theme in this collection.

Berne/TRIPS also has little to say about ownership of copyright. There is real potential, as Giblin points out, to design domestic systems that revert the above-incentive value of copyrights back to creators after some fixed period of time. The US already has one such system in place (though we would hope other countries considering whether to follow suit would adopt a more author-friendly, less formalistic model).${ }^{29}$ Reversion to authors would do much more than simply direct copyright's 'reward' component to its proper recipients. It would also

28 For a detailed discussion of this point, see Kimberlee Weatherall, 'Safeguards for Defendant Rights and Interests in International Intellectual Property Enforcement Treaties' (2016) 32 American University International Law Review 211 (discussing the degree of flexibility in the enforcement provisions of TRIPS).

29 See e.g. Lionel EF Bentley and Jane C Ginsburg, “"The Sole Right ... Shall Return to the Authors": Anglo-American Authors' Reversion Rights from the Statute of Anne to Contemporary U.S. Copyright' (2010) 25 Berkeley Technology Law Journal 1475. 
free up many of those works that had been languishing in the hands of intermediary owners with no further interest in commercially exploiting them, facilitating the transfer of rights to those who value them most. Furthermore, if authors were positioned to capture a greater share of the revenues from their works, it would open up new possibilities for socially valuable collective licensing arrangements (such as digital public libraries that pay fair remuneration to authors on a per-loan basis). Finally, reversion to authors would change the reform discourse. Currently, proposals to ameliorate the overreach of existing approaches are responded to with clockwork regularity by scare campaigns framed around the image of literary and artistic icons losing control of their masterworks. Focusing more squarely on the just deserts of authors could help the debate actually move forward, to identify where the interests of cultural intermediaries and authors cease to align, and better understand what we owe to each.

In addition, Berne/TRIPS' lack of hard rules on ownership might also allow de Beer's aims of limiting idiosyncratic divisions of ownership, and Ncube's suggestion that sometimes it might be appropriate to limit creators' assignments of copyright. Berne/TRIPS would also seem to have little to say about Senftleben's ideas for ensuring a right to fair remuneration, and ex post remedies in cases where remuneration appears disproportionately low in light of the market success of a work.

So not all the ideas in these collected chapters are impossible. In that, they complement some other recent projects which have done excellent work in seeking to frame a general and overarching agenda for achievable copyright reform such as Samuelson et al's Copyright Principles Project in the US or the Wittem Group Draft Model Copyright Code for the EU. To us though, these ideas for feasible change feel very much like mere tinkering at the edges of what's demonstrably a deeply flawed system.

Further, even more minor and creative suggestions not precluded by TRIPS or Berne may be in the process of being closed off by recent, more prescriptive trade agreements. For example, creative rules around ownership and non-assignability of rights, designed to protect individual creators, may be prevented by US-driven free trade agreement provisions stating that 'any person acquiring or holding any economic right in a work, performance, or phonogram ... may 
freely and separately transfer that right by contract' ${ }^{30}$ This provision appears to be designed precisely to counter European-style schemes for fair remuneration of authors and non-assignable rights to equitable remuneration. ${ }^{31}$ And some of the existing flexibility around enforcement is under pressure in the context of recent bilateral and plurilateral IP negotiations. ${ }^{32}$

We are frequently told that the complex IP treaties being drafted today are acceptable because they merely reflect current levels of protection, and demand no changes to current domestic law. This is intuitively troubling: the problem with prescriptive rules is not just the changes they require right now, but also the changes they preclude in the future. But lost future opportunity does not feel like a loss: it needs to be made tangible. Some of the more achievable ideas in this collection give substance to what we might be losing right now.

\section{Why entertain the impossible?}

This brings us to our last big question: what is the practical significance of a collection of impossible ideas? Are these assembled chapters a mere requiem to what might have been?

We don't think so. Even apart from providing another position in the debate over current international treaty-making, for us, the exercise of reimagining copyright from a blank slate has proved a valuable lens for discovering fresh insights about the deficiencies of existing approaches. Thinking about redesigning elements of copyright from scratch necessarily involves deep thinking about what we want it to achieve. From there, new possibilities start to emerge.

\footnotetext{
30 See e.g. Australia-United States Free Trade Agreement, opened for signature 6 May 2004, signed 18 May 2004, [2005] ATS 1 (entered into force 1 January 2005), Art 17.4.6.

31 See analysis in Robert Burrell and Kimberlee Weatherall, 'Exporting Controversy? Reactions to the Copyright Provision of the U.S.-Australia Free Trade Agreement: Lessons for U.S. Trade Policy' (2008) 2 University of Illinois Journal of Law, Technology and Policy 259.

32 See generally Weatherall, above n 28 .
} 
Duration is again a useful example. Implicitly, debates over term generally compare long terms to ones of shorter duration, as if that were the entire universe of options. ${ }^{33}$ Simple reductions in term, however, look like they're just taking away from already struggling authors. But this reimagination exercise - and the recognition that we have distinct goals for both authors and disseminators - leads one to recognise the possibility of more creative alternatives that could be good for a very wide range of stakeholders. Enter Giblin's proposal for different terms designed to satisfy our different rationales for copyright; where the author does not need to give up everything for all time before public exploitation of their creativity has even begun. Copyright is non-zero-sum. Unlike in a zero-sum game (where participants' gains and losses of utility are exactly balanced by those of the other players) a reallocation of copyright's rights - giving producers (only) what they need, and authors and society the rest could potentially result in an enormous increase of utility for some in exchange for just a small reduction for others (or perhaps even no reduction at all). But with international constraints closing off many possible options, this potential is largely going unexplored.

Or take another example from enforcement: from the perspective of an individual creator concerned about rampant infringement, any new enforcement initiative, and any extensions or elaborations of the TRIPS provisions relating to enforcement, must seem inherently a good thing, even if in reality it creates only tools accessible to the largest, most organised right holders. But present that same creator with an alternative that halts the endless expansion of tools, but better and more effectively targets the public resources available, and it could well be more attractive. Similarly, copyright registration may look like an intolerable burden until you start imagining a system of streamlined digital deposit that gives access to enticing procedural or remedial advantages over the way that things work now.

33 There are some notable exceptions: see e.g. the well-known alternative proposed by Landes and Posner of indefinitely renewable copyright terms, William M Landes and Richard A Posner, 'Indefinitely Renewable Copyright' (2003) 70 University of Chicago Law Review 471; (and see also Giblin's criticisms of that approach in her reimagination of duration policy within this book). 


\section{Some hope for the future}

As we mentioned above, when we really pushed ourselves to think about a path to useful reform, we couldn't find a politically feasible pathway to a reimagined copyright system in the public interest in the short to medium term. But despite the generally pessimistic tone of this concluding chapter, we do have some hope for change when we step back and take a longer view. As creators and the broader public become more aware about what existing rules force us to forsake, as global society moves further and further from the worlds which Berne and even TRIPS were formed in response to, it seems to us that something will simply have to give.

In some limited contexts we see faint evidence that this is starting to happen: in the voluntary registers of rights identified by Gangjee; in the increasing efforts of authors to reclaim rights or protect open access through organisations such as the Authors' Alliance (and those of academic and self-published authors to retain their copyrights and only licence to publishers the rights they need). Voluntary efforts will never be enough because so many issues with current copyright arise from the mass of unvalued material that's locked away by long terms and poor record keeping. But they are something.

Crucially though, we think that real change will only occur with serious support from the stakeholders at the very centre of the copyright equation: authors and creators, particularly those who rely on it in some way for their livelihoods. This book has shown how copyright fails its supposed primary beneficiaries. A system in which the lion's share of rewards goes to everyone but creators, and in which important non-economic interests such as attribution and integrity are promoted in only the most incomplete ways, doesn't meet creators' needs. In theory, if creators could be convinced that an alternatively framed system could genuinely offer them more of what they want and need, perhaps they might rethink the political support or cover they provide to the current system, and their resistance to changing it.

Based on some of the ideas presented in the this book, it is possible to imagine a more author-friendly kind of copyright: one that provides opportunities to recover and renegotiate exploitation rights and protects authors against being obliged to assign all rights for all time to obtain access to audiences and distribution channels (Giblin); 
that provides mechanisms for sharing in the bounty of particularly successful works (Senftleben); that still protects rights of attribution and integrity for long periods regardless of formalities (Gangjee); that provides for much-simplified rights of remuneration or enforcement for registered works (Gangjee, Weatherall). A system that promoted (or even, consistent with the theme of reciprocity, required) access to material that was no longer commercially available could provide a plentiful supply of source material for future creation.

We see this as a long-term hope. We would not expect those creators succeeding in the current winner-takes-all system to advocate for change. Others will quite understandably be unwilling to give up whatever (measly) rewards they do eke out from current copyright systems: when you accrue but little directly from your creativity, giving any of that up is a big deal. With the intricacies of copyright law now largely inaccessible to all but lawyers heavily invested in the system, relatively few authors are ever likely to engage sufficiently with the detail of copyright law to be able to reach the conclusion that current settings so disserve their interests that they should lobby in favour of systemic change. We suspect that most creators have enough to worry about in developing their own creative practice, producing their music, or art, or words, and in managing the day-today business of a creative career. But we hope there will come a time when enough is enough: when enough creators will stop accepting that 'some copyright is good, so more copyright must be better' and start agitating for a system that genuinely serves their interests, rather than simply permitting their genuine claim to be used as a stalking horse for other economic interests.

\section{Not an end, but a beginning}

The strength of this collection - its highly skilled and hardworking team of international legal academics - is also one of its weaknesses.

The brief we started with is challenging for the legally trained thinker. Lawyers are accustomed to think within the framework of existing systems: to identify specific problems and propose incremental fixes and reforms that do not drastically challenge the foundations of the law. A blank slate is, frankly, both disconcerting and confronting. As lawyers, too, we tend immediately to see the problems with radical 
proposals, which can perhaps render us quick to dismiss, rather than embrace ideas that depart markedly from the norm. As Gangjee eloquently notes in his chapter, it is hard to let go of the edge of the pool and strike out for something new. We certainly had to push ourselves (and our colleagues, whom we thank for their tolerance) to think more radically, to be more adventurous, and to question preconceptions about the way things could and should be.

The proposals here reflect these challenges. They may put to one side the existing international and domestic legal framework, but it would be fair to say that most still operate within traditional understandings of what copyright is designed to achieve and accept the basic premise of achieving those goals within a framework of authors' proprietary rights, albeit, in some cases, with plenty of qualifications. So there is room to push our premise considerably further in the future. In particular, we have found in talking about these ideas and our initial premise with thinkers or audiences beyond the legally trained, that there's enormous scope for even more creative ideas to emerge. ${ }^{34}$

And so we invite the reader to try for themselves the exercise of trying to reimagine copyright without the safety net of current legal frameworks. We can certainly recommend it as an intellectual exercise. It may not be comfortable, or easy, but even the process of thinking up radical alternatives can not only spark some interesting ideas but it can also put existing problems in a new light. Copyright touches on all of our lives - and the conversations exploring how it might best achieve its aims should also be informed by a diverse range of perspectives and voices.

34 For example, one of the authors (Giblin) spoke on these ideas at the 2016 Annual Forum of the Australian Digital Alliance (March 2016), and invited a panel of non-lawyers to contribute their own ideas taking the same premise as a starting point. Their ideas can be seen in a video of the forum, available on YouTube at $<$ www.youtube.com/watch?v=JsXWt7GrBbE $>$. 
This text is taken from What if we could reimagine copyright?, edited by Rebecca Giblin and Kimberlee Weatherall, published 2017 by ANU Press, The Australian National University, Canberra, Australia. 